\title{
RURAL AREAS IN POLAND: EDUCATIONAL ATTAINMENT VS. LEVEL OF ECONOMIC DEVELOPMENT
}

\author{
WiOLETTA KAMIŃSKA \\ Institute of Geography, Jan Kochanowski University in Kielce, Poland \\ Manuscript received: January 27, 2013 \\ Revised version: August 20, 2013
}

\begin{abstract}
KAmińsKA W., 2013. Rural areas in Poland: Educational attainment vs. level of economic development. Quaestiones Geographicae 32(4), Bogucki Wydawnictwo Naukowe, Poznań, pp. 63-79, 5 tables, 4 figs. DOI 10.2478/quageo-2013-0034, ISSN 0137-477X.

AвSTRACT: The aim of this article is to analyse relations between the educational attainment of the rural population and the level of economic development of the rural areas in Poland. A typology of communes in terms of the analysed relations is made. This is the first research of this type involving all the rural areas in Poland conducted at the level of the commune. The research has shown a significant linear relation between the educational attainment of the population and the level of economic development of rural areas. The correlation coefficient amounts to 0.565 .
\end{abstract}

KEY WORDS: rural areas, education, economic development, communes

Wioletta Kamińska, Institute of Geography, Jan Kochanowski University, Świętokrzyska 15, 25-406 Kielce, Poland; e-mail: wioletta.kaminska@ujk.edu.pl

\section{Introduction}

Globalisation and European integration processes intensifying at the turn of the $20^{\text {th }}$ and $21^{\text {st }}$ centuries changed the conditions for operating a business. The global economy leads to the globalisation of enterprises' activity, which is expressed, e.g., in moving production to any place in the world.

Immaterial development factors, such as the education of a population, gain in importance in those new circumstances. One can even observe that economic success, both of regions and enterprises, is strongly related to the level of knowledge, skills and professional experience of the citizens. Bacon's (1620) thought has recently been more and more often cited in the literature on the subject: "knowledge is power". Thurow (1999: 422) adds that the competitive advantage of every region depends on the "readiness and capability of making long-term social investments in qualifications, education, knowledge and infrastructure". Many authors also think that the underdevelopment of some countries is a consequence of the slow progress in education, which significantly delays the technology transfer (Thurow 1999; Adebiyi, Oladele 2005; Przybyszewski 2007; Baldacci et al. 2008; Hanushek, Woessmann 2012; Jimenez et al. 2012).

In Poland, the most abundant resources of qualified workforce are concentrated in the cities. Rural areas have for years been characterised by an outflow of people (Eberhardt 1989, Rosner 2011), including the best educated ones. This is due to the unattractive living and working conditions in the countryside and the fact that agriculture was perceived as a sector hardly suitable for qualified workforce. 
Meanwhile, along with the progressing European integration, Polish rural areas and agriculture turned out to be uncompetitive (Zegar 2000), while the monofunctional model of development did not fit the changing market conditions anymore (Stasiak 2000). Thus, new strategies for the development of the countryside aimed to make it multifunctional. Non-agricultural functions kept emerging dynamically but unequally in the rural space (Bański 2003, Kamińska 2005), leading to significant regional disproportions (Heffner, Rosner 2005, Kłodziński 2006, Rosner 2007, Kamińska 2011a). Differences in the educational attainment of the country people are more and more often numbered among factors favouring spatial divergence (Kamińska, Heffner 2010, 2011).

Therefore, a question arises of whether the population's education is a factor which stimulates the economic development of the Polish rural areas. This is an arguable question: my research (Kamińska 2012) conducted in the rural areas of Świętokrzyska Land has not confirmed there to be any relation between the level of the population's education and the level of economic development.

In the light of the above remarks, the aim of this article is to analyse the relations between the educational attainment of the population of the rural areas in Poland and the level of their economic development. Also, an attempt is made to create a typology of communes (gminas, principal units of Poland's territorial and administrative division) in terms of the analysed relations.

\section{Research methods}

The research process included three stages. First, spatial diversification of the educational attainment of the rural population was determined; secondly, the level of economic development of each territorial unit was estimated; thirdly, the relation between the educational attainment of the population and the level of economic development was analysed. Each of these stages closed with a typology of communes by the analysed feature.

Such a procedure required the selection of appropriate measures (variables). It was assumed that the measures should be precisely defined, objective and credible, accessible and measurable, as well as uncorrelated (Grootaert, van Bastelaer 2002).

Three measures were adopted to analyse the educational attainment of the rural population (Table 1) involving its formal education. Their advantages and disadvantages have been described in detail in the literature on the subject (Judson 1998, Kamińska 2011b, and others).

The data concerning the education of the rural population (including farmers) give information about the possibilities for innovation creation and absorption. Those on the formal preparation of councillors allow drawing conclusions about the possibility of performing creatively their functions in local governments and the importance of education in making electoral decisions by the rural population.

It is assumed in the paper that economic development is a series of subsequent economic phenomena which, on the basis of common knowledge, may be assessed as more favourable for a given society than others (Hryniewicz 2000). Its level can be defined on the basis of the economic structure of rural areas (taking into consideration the agricultural and the non-agricultural sector), the labour market, and the wealth of the territorial units (Rosner 2007; Stanny, Czarnecki 2011).

Initially, 12 measures were adopted. Finally, after the statistical analysis and elimination of

Table 1. Coefficients of correlation between measures of educational attainment.

\begin{tabular}{|c|c|c|c|}
\hline & $\begin{array}{c}\text { Percentage of people } \\
\text { with at least secondary } \\
\text { education }\end{array}$ & $\begin{array}{c}\text { Percentage of local } \\
\text { councillors with higher } \\
\text { education }\end{array}$ & $\begin{array}{c}\text { Percentage of farms operated } \\
\text { by people with at least secondary } \\
\text { agricultural education }\end{array}$ \\
\cline { 2 - 4 } & M-1 & M-2 & M-3 \\
\hline M-1 & 1.000 & 0.320 & 0.010 \\
\hline M-2 & & 1.000 & 0.113 \\
\hline M-3 & & & 1.000 \\
\hline
\end{tabular}


strongly correlated features, eight measures were selected (Table 2).

Measures describing the agricultural sector provide information about the condition of individually operated type of farming. This is an important aspect of the economy of Polish rural areas, which are characterised by a high share of the agricultural function, both in terms of employment and sources of income. The low workforce productivity, low marketability of production, and fragmentation of farms are barriers to the economic development of the countryside.

In turn, the measures adopted for describing the non-agricultural sector define the level of diversification and de-agrarisation of the local rural economy. A well-developed non-agricultural sector not only creates additional workplaces and sources of income for the rural population, but also accelerates structural transformation in agriculture, which leads to a decrease in agricultural employment.

The unemployment rate informs about the level of equilibrium in a labour market. As Ros- ner and Stanny show (2007: 34), "excessive employment in agriculture (agrarian overpopulation) appears on family farms when the labour market is not in the state of equilibrium (...). A tendency to escape from the labour market into occupational inactivity and search for unearned sources of income intensifies". In turn, the number of people working outside agriculture per 100 people employed in agriculture informs about the diversification of the labour market and the local rural economy.

The mean of a commune's own revenue (between 2005 and 2011) per inhabitant served as a measure of the wealth of its local government. This measure provides indirect information about the economic activity of the rural population, the level of the commune's investment attractiveness as well as entrepreneurship and the local government's efficiency in obtaining EU funds.

Hellwig's (1968) method of a distance to a model object was applied in order to determine spatial differences in the level of human capital and economic development. It involves compar-

Table 2. Coefficients of correlation between the measures of economic development.

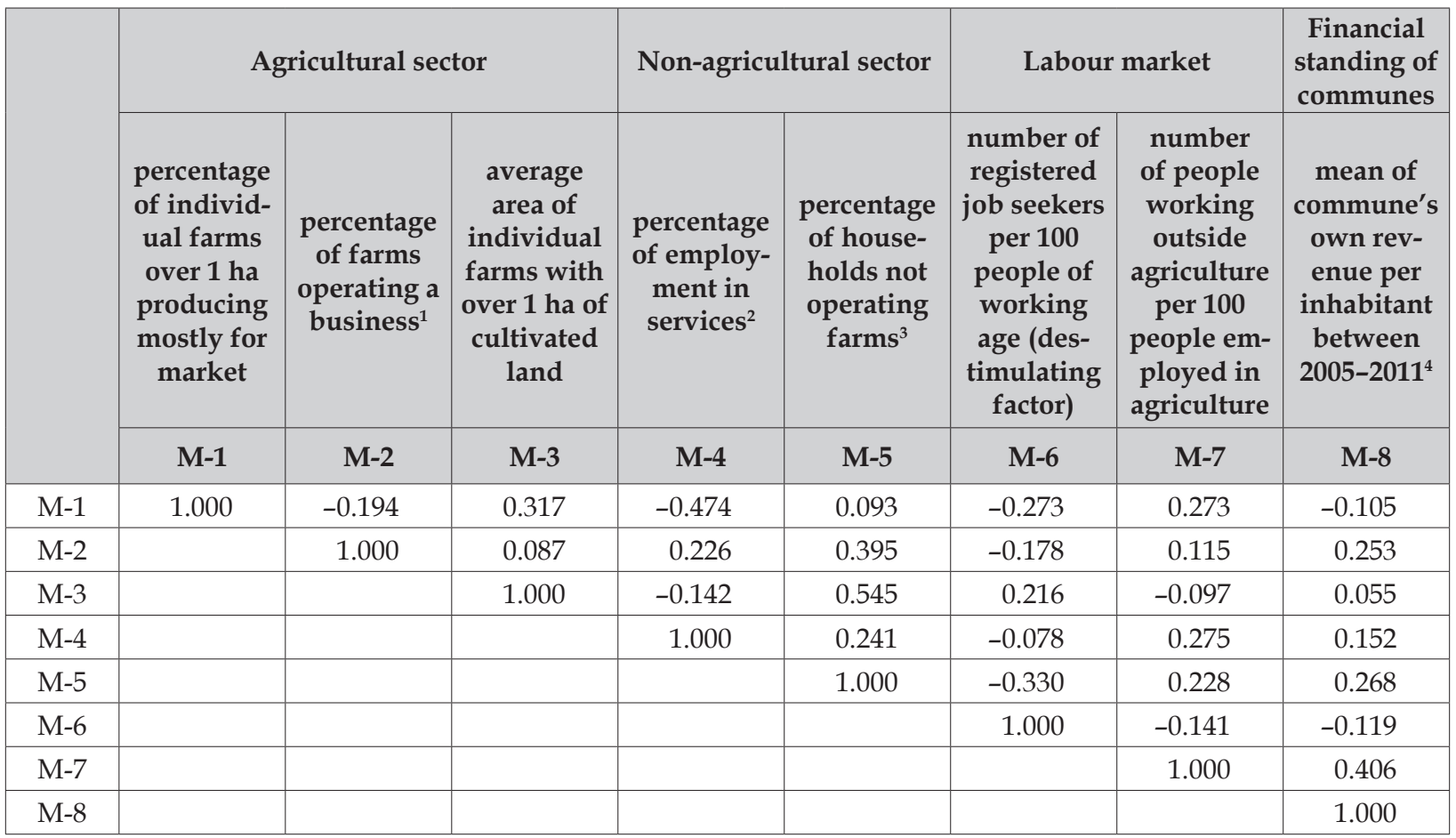

${ }^{1}$ Percentage of farms operating a business is strongly correlated with the number of private entities registered in the REGON (National Economy Register) system. The correlation coefficient amounts to 0.6624

${ }^{2}$ Percentage of employment in services is strongly correlated with the percentage of farms producing mostly for the market $(\mathrm{r}=-0.5737)$.

${ }^{3}$ Percentage of households not operating a farm is strongly correlated with the employment rate $(\mathrm{r}=0.554)$.

${ }^{4}$ Mean of a commune's own revenue per inhabitant is correlated with the commune's investment expenditure $(\mathrm{r}=0.6121)$.

Source: Own calculations. 
ing a set of $n$ objects $(i=1,2, \ldots, n)$ for $p$ selected features $(k=1,2, \ldots, p)$, which can be presented in the form of a matrix:

$$
\boldsymbol{X}=\left[\begin{array}{cccc}
x_{11} & x_{12} & \ldots & x_{1 p} \\
x_{21} & x_{22} & \ldots & x_{2 p} \\
\ldots & \ldots & \ldots & \ldots \\
x_{n 1} & x_{n 2} & \ldots & x_{n p}
\end{array}\right]
$$

The coordinates of the model object were determined on the basis of the maximum values of the features observed in the whole set. The distance of each commune from the model object was calculated after standardisation according to the formula:

$$
C_{i 0}=\sqrt{\sum_{j=1}^{k}\left(z_{i j}-z_{0 j}\right)^{2}}
$$

where:

$\mathrm{C}_{\mathrm{i} 0}$ - the distance between commune $i$ and the model object

$\mathrm{z}_{\mathrm{ij}}$ - the value of the $j$-th feature in the $i$-th commune after standardisation

$\mathrm{z}_{0 \mathrm{j}}$ - the value of the $j$-th feature in the model object. Calculated next was the synthetic index $d_{i}$ :

$$
d_{i}=1-\frac{C_{i o}}{C_{o}}
$$

where:

$\mathrm{C}_{0}=\overline{\mathrm{C}}_{0}+2 \mathrm{~S}_{0}$,

$\mathrm{C}_{\mathrm{i} 0}$ - the commune's distance from the model object $\bar{C}_{0}$,

$\overline{\mathrm{C}}_{0}$ - the arithmetic mean of the commune's distance from the model object,

$\mathrm{S}_{0}$ - the standard deviation of the commune's distance from the model object.

A typology by the level of education and economic development of the analysed objects was made on the basis of the synthetic index $d_{i}$. Then, taking the relation between the analysed features as the criterion, nine types of commune were distinguished:

1. at a high level of education and a high level of economic development, if $d_{i}>\bar{d}_{i}+0.5 \mathrm{~S}_{0}$ in both cases (where $\bar{d}_{i}$ is the mean of measure $d_{i}$ and $S_{0}$ the standard deviation of measure $d_{i}$ ),

2. at an average level of education and an average level of economic development, if $\bar{d}_{i}-0.5$ $\mathrm{S}_{0}<d_{i}<\bar{d}_{i}+0.5 \mathrm{~S}_{0^{\prime}}$
3. at a low level of education and a low level of economic development, if $d_{i}<\bar{d}_{i}-0.5 \mathrm{~S}_{0}$ in both cases,

4. at a low level of education $\left(d_{i}<\bar{d}_{i}-0.5 S_{0}\right)$ and a low level of economic development,

5. at an average level of education $\left(d_{i}>\bar{d}_{i}+0.5 S_{0}\right)$ and a low level of economic development,

6. at an average level of education $\left(\bar{d}_{i}-0.5 \mathrm{~S}_{0}<d_{i}<\right.$ $\left.\bar{d}_{i}+0.5 \mathrm{~S}_{0}\right)$ and a high level of economic development $\left(d_{i}>\bar{d}_{i}+0.5 \mathrm{~S}_{0}\right)$,

7. at a low level of education $\left(d_{i}<\bar{d}_{i}-0.5 \mathrm{~S}_{0}\right)$ and an average level of economic development $\left(\bar{d}_{i}-0.5 \mathrm{~S}_{0}<d_{i}<\bar{d}_{i}+0.5 \mathrm{~S}_{0}\right)$,

8. at a high level of education $\left(d_{i}>\bar{d}_{i}+0.5 \mathrm{~S}_{0}\right)$ and an average level of economic development $\left(\bar{d}_{i}-0.5 \mathrm{~S}_{0}<d_{i}<\bar{d}_{i}+0.5 \mathrm{~S}_{0}\right)$, and

9. at an average level of education $\left(\bar{d}_{i}-0.5 \mathrm{~S}_{0}<d_{i}<\right.$ $\left.\bar{d}_{i}+0.5 \mathrm{~S}_{0}\right)$ and a low level of economic development $\left(d_{i}<\bar{d}_{i}-0.5 \mathrm{~S}_{0}\right)$.

It is worth underlining that the first three types confirm the relation between education and the level of economic development, while types four and five diverge completely from the general regularity.

\section{The influence of education on economic development - an outline of the issue}

The relation between education and economic development has been proved in both, theoretical and empirical research.

The thesis to the effect that education and its appropriate use is one of the most important factors affecting the economic development of nations emerged in the papers of such economists as William Petty $(1676,1899)$, Adam Smith $(1776$, 1979), Karl Marx (1867, 1890), John Stuart Mill $(1848,1909)$ and others. However, it was only in the second half of the $20^{\text {th }}$ c. that education was introduced permanently into the economy as a factor of production in development models.

These models, based on the concepts of human capital, show there to be a close relation between education and technological change (Nelson, Phelps 1966; Lucas 1988) as well as between knowledge and productivity and the pace of technology diffusion (Arrow 1962; Nelson, 
Phelps 1966; Romer 1990). According to Jimenez et al. (2012: 4), in these models the authors "distinguish human capital's contribution to economic growth by introducing two concepts. First, beyond the quantity of human capital, output also depends upon the average level of human capital. Second, human capital is endogenous, rather than exogenous, in the system in the sense that it is produced by using resources. The implication of these conceptual insights is that "knowledge" becomes a public good that spills over into the economy as an additional source of growth. For countries this means that they do not converge to a common steady state path; they can grow at different rates - as can per capita incomes. Another, equally important implication of this mod$\mathrm{el}$ is that, by virtue of the average stock of human capital being available to all, there might be social underinvestment in human capital formation".

Also empirical studies provide ample proof of the relation between education and economic development. They focus on three areas (Wilson, Briscoe 2004):

1. rate of return on investment in education and improvement of qualifications,

2. significance of education for economic growth and the development of enterprises, and

3. positive externalities created due to investment in education.

The groundbreaking papers by Miller (1960) and Becker (1964) should be mentioned in the first group. The authors conducted calculations concerning the profitability of university studies and on that basis they found that the rate of return on an investment in studies is almost the same as in the case of investment outlays in the financial market, the real-estate market, or bank deposits. It has been unequivocally found that education increases individual revenues over the amount of outlays (Psacharopoulos, Patrinos 2004).

The above calculations were conducted at micro- and macro-levels, and concerned incomes of individual people ${ }^{1}$. However, as Wilson and Briscoe (2004) conclude, what is good for individual people is also good for a whole society.

\footnotetext{
An overview of literature on the rate of return on investment in education can be found in Sianesi, Van Reenen (2000), Harmon, Walker (2001), Blundell et al. (2001), Barret (2001), Cooray (2009), Acemoglu, Autor (2012), and Jimenez et al. (2012).
}

Buchinsky (1994) conducted a similar research in the USA, Mwabu and Schultz (1996) in South Africa, Harmon et al. (2003), Denny and O'Sullivan (2007) in Great Britain, and Jimenez et al. (2012) in European countries. In general, what results from them is that additional schooling reduces conditional wage dispersion and that education and abilities are substitutes in terms of the generation of earnings.

Also the research conducted in transforming economies (Fleisher, Wang 2004; Munich et al. 2004; Newell, Socha 2005; Flabbi et al. 2007) provides interesting results related to the rate of return on educational input. The authors found that returns to education increased from the "pre-transition" to the "early transition" period. Moreover, Fleisher and Wang (2004) suggest that the sharp increases in the returns to education took place during the early transition (the early 1990s). In turn, Flabbi et al. (2007) found that the examined countries can be classified into three broad groups: a "high" returns group (Hungary and Poland), an "average" returns group (Bulgaria, Latvia, Slovenia and Russia), and a "low" returns group (the Czech and Slovak Republics).

Studies conducted in the 1960s and '70s (Kendrick 1961; Harbison, Meyers 1964; Denison 1971) and later (Heston et al. 2002; de la Fuente, Ciccone 2003; Schlump, Brenner 2010; Kharas, Kohli 2011) belong to the second group of the research papers describing the relations between education and the economic development of nations and enterprises. On the basis of their research, the authors found that:

- high outlays for education are necessary for the economic development of a nation (Kendrick 1961; Harbison, Meyers 1964; Mankiw et al. 1992),

- there is a direct relation between the condition of education and the level of economic development of a nation (Kendrick 1961; Harbison, Meyers 1964; Denison 1971; Heston et al. 2002),

- activity of research institutions and universities may influence employment growth (Kirchhoff et al. 2007),

- higher education of the population and existing research institutions affect employment growth in a local economy (Schlump, Brenner 2010), 
- all nations understand that educational attainment is a basis for getting a job and achieving success in life (Harbison, Meyers 1964; Thurow 1999), and

- "a good education system is fundamental for equipping workers with the right skills, because an educated population earns more and education provides people with the cushion and the life skills to avoid falling back into poverty" (Jimenez et al. 2012).

Some researchers have sought to assess the influence of education on economic growth. Thus, Kendrick (1961) calculated that between 1889 and 1957 approximately 50\% of production growth was a result of increased effectiveness and use of financial outlays thanks to the educational improvement of the workforce. Denison (1971) found that between 1929 and 1957 workforce productivity in the United States had increased by $19.6 \%$ as a result of qualifications improvement. This author also calculated that during his study period the education of an average employee grew by almost $2 \%$ per year, which translates into an increase of workforce productivity by almost 0.97\%. Also Mankiw, Romer and Weil (1992) confirmed the significant influence of education on the wealth of nations. The authors calculated that a $10 \%$ increase in human capital translated into a growth of per capita GDP by $6.7-7.6 \%$. Barro (1998) found that every additional year of learning at the secondary level resulted in an increase of the future economic growth rate by at least 0.7 pp. In turn, de la Fuente and Ciccone (2003) proved that every additional year of education in an average European state could lift workforce productivity by even $6 \%$.

A positive correlation between the gross enrolment ratio (at the secondary and higher school levels) and per capita GDP has also been confirmed in the latest studies (Barro, Lee 2000, Heston et al. 2002, Fleischer et al. 2008, Cooray 2009).

The authors of recent researches put more emphasis on the quality of education than on its length. Hanushek and Woessmann (2008) found strong evidence that the cognitive skills of the population - rather than the mere school attainment - are closely related to individual earnings, to the distribution of income, and to economic growth. According to Jimenez et al. (2012: 5) "It is not only more years of education, or even high quality education, that matters - it is also the type and amount of skills imparted by such education. Aside from the basic cognitive skills such as literacy and numeracy, two other skill types are important: generic skills such as team working and communication, and occupation-specific skills. Most occupations require a blend of different skill types, with a specific ability level within each".

The third field of research includes papers about positive externalities of investment in education (Acemoglu 1996, de Barros et al. 2000, McMahon 2001). The authors conclude that the benefits from investment in improving qualifications not only affect the people engaged in this investment, but they spill over to the whole society (Wilson, Briscoe 2004). Well educated citizens are characterised by a higher workforce productivity than their less educated colleagues, whereas companies employing highly qualified staff use their real capital in a superior way and invest more in research and training (Acemoglu 1996). According to de Barros et al. (2000: 43), "education has also an important direct impact on population growth, parental care and political participation. Through these channels education can further improve efficiency, reduce poverty and facilitate social mobility". McMahon (2001) estimates that approximately $75 \%$ of benefits may be of non-marketable character. And, though it is difficult to include them in growth models, their influence on economic development is indisputable. Those benefits are: health, life expectancy, natal mortality, reduction of delinquency, society's attitude towards the natural environment, democratisation of public life, civil rights enforcement, etc.

The research on the relations between education and the various aspects of the economic development of rural areas proving a correlation between these features has also been conducted in Poland (Kulikowski 2002; Janc, Czapiewski 2005).

It is worth underlining that there are studies which do not demonstrate a close relation between education and the level of economic development (Barro, Lee 1996; Caselli et al. 1996; Bils, Klenow 2000; Prichett 1999a, b, 2001). By applying advanced econometric tools, those authors have demonstrated the influence of education on the economic development rate to be negative, or not so obvious as described above. Critics of the 
human capital theory argue that education which does not teach any real skills does not influence significantly either the nation's wealth or its management. However, because employers use it to evaluate candidates in the recruitment process or promotion, higher education leads to getting higher positions and bigger salaries (Grodzicki 2003; Wilson, Briscoe 2004).

\section{Differences in the educational attainment of the rural population}

The calculated synthetic index of the educational attainment of people living in the countryside oscillated between -0.022 and 0.823 . Five types of communes were distinguished using the value of the index as a criterion.

Type one, of communes with a very high educational attainment, included 79 units $(3.6 \%$ of the total number of communes) inhabited by 949.8 thousand people, or $6.3 \%$ of the rural population (Table 3, Fig. 1). Those were primarily suburban areas of national and regional urban centres and, secondly, some communes with specific restructured fields of the economy, such as seaside communes or those located in the Bieszczady Mountains, which are popular and attractive for tourists. In both cases these areas were characterised by an extraordinary development of non-agricultural functions in relation to Poland (Bański, Stola 2002), net in-migration, as well as a $5 \%$ population increase over the last decade (Rosner 2011).

The biggest number of communes at a very high education level of the population, by voivodeship, were located in Mazovia (19), West
Pomerania (9) and Wielkopolska (9), and the least, in Świętokrzyska Land (1).

Areas at a high education level of the rural population constituted the second type of communes. This group included 161 (7.4\%) territorial units inhabited by 1.5 million people $(9.9 \%$ of the inhabitants of the Polish countryside). They usually border upon communes with the most favourable educational attainment of the population and are characterised by intense development of non-agricultural functions and growth in the number of inhabitants. This is natural, as a well-developed non-agricultural labour market is a factor which attracts highly qualified people. The biggest number of communes of the analysed type represented Silesia (23) and Mazovia (20) as well as Lublin, Subcarpathia and Wielkopolska (13 units in each). The least number of communes were located in Warmia-Mazuria (2) and Lubuska Land (3).

638 communes $(29.4 \%)$ inhabited by almost one-third of the rural population of Poland, were included in type three, characterised by an average education level of country people. They differed in their share of the development of agricultural and non-agricultural functions in the economic structure (Bański, Stola 2002). However, the following regularity is evident: the shorter the distance between a commune and an urban centre, the more dominating the non-agricultural function in the commune's economic base. With the growth in the distance to a city, the importance of agriculture grows too, and it is usually intensive and commodity type of agriculture. It is worth underlining that these are areas of demographic stagnation or an insignificant (up to $5 \%$ ) population decline (Rosner 2011).

Table 3. Differences in the education level of the rural population in Poland.

\begin{tabular}{|l|c|c|c|c|}
\hline \multirow{2}{*}{ Education level } & \multicolumn{2}{|c|}{ Number } & \multicolumn{2}{c|}{ Percentage } \\
\cline { 2 - 5 } & of communes & $\begin{array}{c}\text { of people } \\
\text { (thousands) }\end{array}$ & of communes & of people \\
\hline very high & 79 & 949.8 & 3.6 & 6.3 \\
\hline high & 161 & $1,504.2$ & 7.4 & 32.8 \\
\hline average & 638 & $4,966.3$ & 29.4 & 41.4 \\
\hline low & 1,006 & $6,274.3$ & 46.3 & 9.6 \\
\hline very low & 289 & $1,458.0$ & 13.3 & 100.0 \\
\hline total & 2,173 & $15,152.6$ & 100.0 & \\
\hline
\end{tabular}

Source: own calculations. 


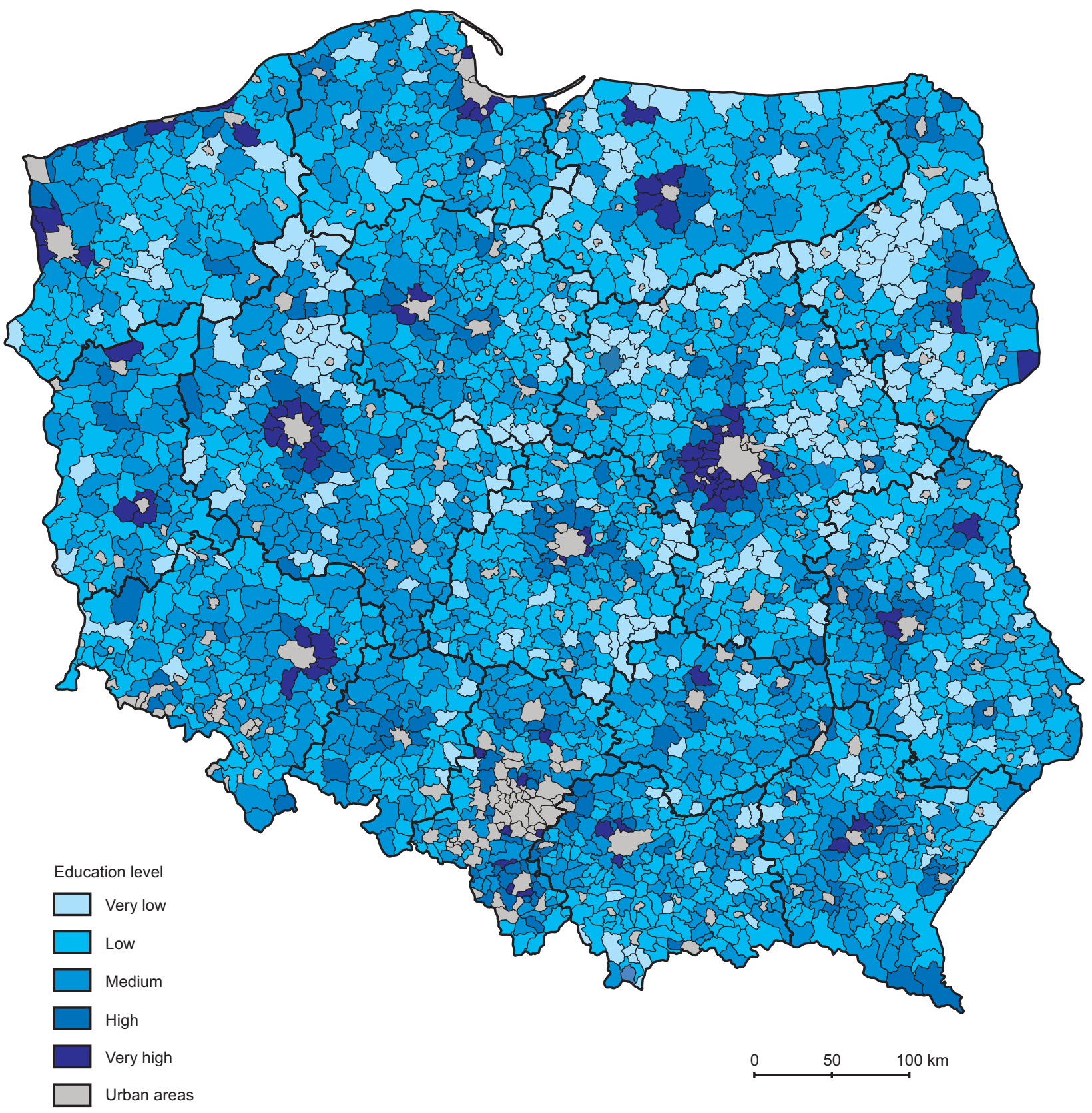

Fig. 1. Differences in the education level of the rural population - a synthetic index. Source: own elaboration.

Finally, the fourth and the fifth types of communes are areas with a low and a very low educational attainment of the population. Altogether, these two types included as many as 1,295 communes $(59.6 \%$ ) inhabited by more than a half of Poland's rural population (51\%). Their values of the synthetic index describing the education level were lower than the national average. These are spatial units located in the peripheries of the voivodeships. Their economic structure is dominated by agricultural functions, usually nei- ther intensive nor commodity agriculture. Their net out-migration is a result of the drain of the best-educated part of society.

\section{Spatial differences in the level of economic development}

The synthetic index of the level of economic development in the rural areas of Poland oscillated between 0.0164 and 0.6743 . With this index as 
a criterion, five types of communes were distinguished: at a very high, high, average, low and very low level of economic development (Table 4, Fig. 2).

The first type included 182 units $(8.4 \%)$ inhabited altogether by $11.6 \%$ of the rural population. One can distinguish here the communes located:

- in the suburban zones of the biggest Polish agglomerations with a strong domination of non-agricultural functions; and

- far from urban centres, but with well developed non-agricultural, usually industrial or tourist, functions. Industrial functions were connected with plants of supra-regional importance (e.g. the Bogdanka hard coal mine in the commune of Puchaczów in Lublin voivodeship, or the Bełchatów brown coal mine and power plant in the commune of Kleszczów in Łódź voivodeship), while tourist functions had developed on the basis of the attractiveness of a location for tourists (at the seaside and in the mountains).

The biggest number of communes from the first group are located in the following voivodeships: Silesia (30), Mazovia (25), Wielkopolska (23), and West Pomerania (22). Units located in only four voivodeships account for $55 \%$ of the total number of communes at a very high level of economic development. The lowest number of communes at the highest level of economic development are located in Lublin voivodeship and Świętokrzyska Land (one in each).

The second type - showing a high level of economic development - is represented by 211 (9.7\%) units inhabited by $11.7 \%$ of the rural population. Also in this type one can determine areas located: - in the suburban zones of agglomerations and centres of at least regional importance; in the case of agglomerations, these communes are usually located in the second ring;

- in areas attractive for tourists but less popular than communes representing the first type (the seaside communes of Postomino, Darłowo, Trzebiatów, the mountainous commune of Krynica-Zdrój). Multifunctional development, including well developed tourist functions, are the main factors of the superior level of economic development here;

- far from urban centres, but developing on the basis of well functioning industrial works (e.g. Połaniec in Świętokrzyska Land, where a power plant is located); and

- far from cities, but distinguished by well developed, competitive agriculture (e.g. Brodnica in Wielkopolska). According to Bański (2008), such areas are characterised by high investment outlays for food management and high productivity of farms.

The biggest number of communes of the second type are concentrated in Małopolska (42), Silesia (26), Lower Silesia (26) and West Pomerania (25), and the least, in Lublin (0), Subcarpathia (1), Podlasie (3) and Świętokrzyska Land (3).

The third type included areas at an average level of economic development. This is the most numerous group, with as many as 1,157 communes $(53.2 \%)$ inhabited by half of the rural population of Poland. Those are areas of a dominating agricultural function complemented (to various extents) by industrial, service, tourist, forest and residential functions. The biggest number of such units are located in the western and central voivodeships (Mazovia - 156, Wielkopolska - 122, Łódź - 101, Kujavia-Pomerania - 90), and the smallest, in Świętokrzyska Land (34) and Subcarpathia (40).

Table 4. Differences in the level of economic development of the rural areas in Poland.

\begin{tabular}{|l|c|c|c|c|}
\hline \multirow{2}{*}{$\begin{array}{c}\text { Level of economic } \\
\text { development }\end{array}$} & \multicolumn{2}{|c|}{ Number } & \multicolumn{2}{c|}{ Percentage } \\
\cline { 2 - 5 } of communes & $\begin{array}{c}\text { of people } \\
\text { (thousands) }\end{array}$ & of communes & of people \\
\hline very high & 182 & $1,763.1$ & 8.4 & 11.6 \\
\hline high & 211 & $1,779.9$ & 9.7 & 50.1 \\
\hline average & 1,157 & $7,592.3$ & 53.2 & 23.1 \\
\hline low & 551 & $3,506.7$ & 25.4 & 3.4 \\
\hline very low & 72 & 510.6 & 3.3 & 100.0 \\
\hline total & 2,173 & $15,152.6$ & 100.0 & \\
\hline
\end{tabular}

Source: own elaboration. 


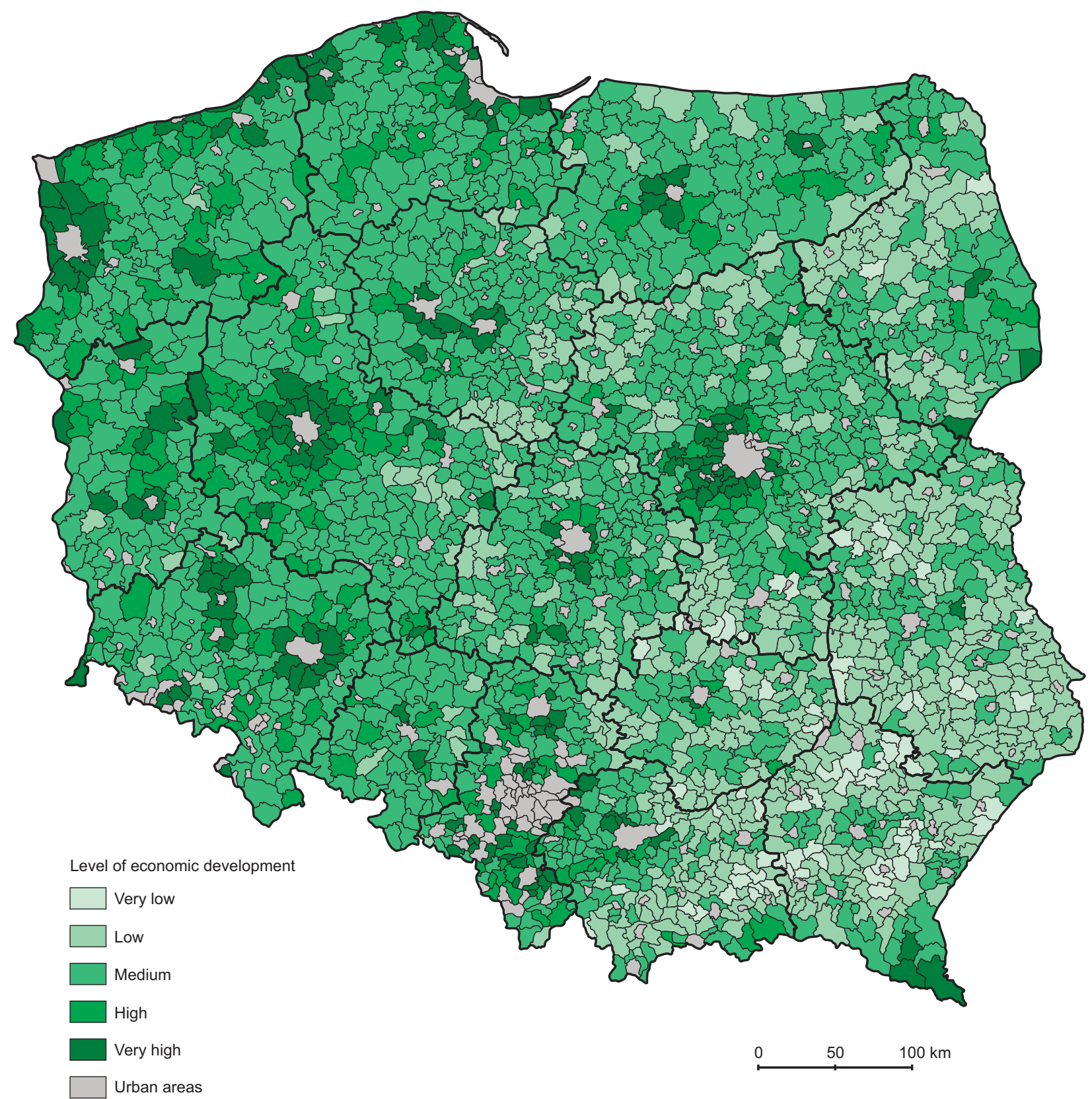

Fig. 2. Differences in the economic development of the rural areas in Poland - a synthetic index. Source: own elaboration.

Types four and five embraced areas at a low and a very low level of economic development. Altogether they included 623 communes (28.7\%) inhabited by $26.5 \%$ of the rural population. Their biggest clusters occur in south-eastern Poland (Świętokrzyska Land, Subcarpathia and Lublin), i.e. in areas dominated by family farming, neither intensive nor commodity oriented (Bański, Stola 2002). Agriculture, sometimes complemented by poorly developed non-agricultural functions, significantly dominates in their economic structure. A slightly bigger cluster of the least developed communes is located in the north-western part of Podlasie. In other voivodeships, communes classified as types four and five are located peripherally.

\section{The relation between education and the level of economic development}

There was a significant relation observed between education and the level of economic development of the rural areas (Fig. 3). The correlation coefficient amounted to 0.565 . 


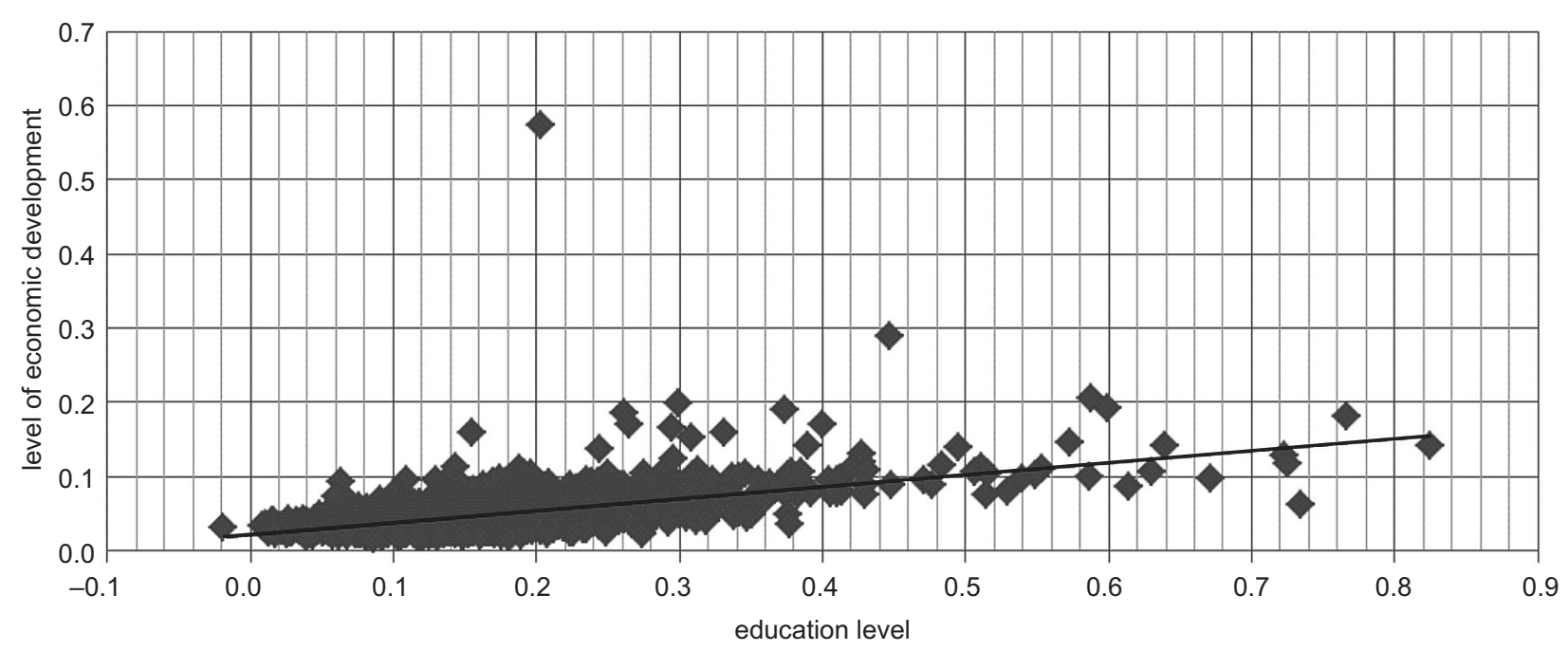

Fig. 3. Relation between education and the level of economic development in the rural areas of Poland. Source: own elaboration.

There was a close relation between the analysed features (types 1-3) in 1,209 communes (i.e. $55.6 \%$ of their total number). From among this number, in only 230 units a high level of education is accompanied by a high level of economic development (Table 5, Fig. 4). Most of them are located in the direct neighbourhood of cities of supra-regional and national importance and/or have a well developed non-agricultural sector.

The biggest number of communes of this type are located in Silesia (44), Mazovia (35) and Wielkopolska (32), and the lowest, in Lubuska Land (0), Subcarpathia (3) and Świętokrzyska Land (3).

A low level of both analysed features was observed in 316 communes concentrated mainly in eastern Poland. Those areas, among the poorest not only in the country but also in the entire Union at the moment of Poland's accession to the European Union, were included in a special operational programme for eastern Poland. They are usually areas of family farming, both fragmented and semi-subsistence.

An average level of educational attainment co-occurs with an average level of economic development in almost one-third of communes. The biggest number of such areas is located in the voivodeships of central (Wielkopolska - 77, Mazovia - 71, Łódź - 58, Kujavia-Pomerania - 49) and western Poland (Lower Silesia - 61).

The communes classified into types four and five deserve special attention. There are areas in

Table 5. Relation between education and the level of economic development in the rural areas of Poland.

\begin{tabular}{|c|l|c|c|c|c|}
\hline \multirow{2}{*}{$\begin{array}{c}\text { Type } \\
\text { number }\end{array}$} & \multirow{2}{*}{$\begin{array}{c}\text { Relation between education and level } \\
\text { of economic development }\end{array}$} & \multicolumn{2}{|c|}{ Number of } & \multicolumn{2}{c|}{ Percentage of } \\
\cline { 4 - 6 } & & communes & $\begin{array}{c}\text { people } \\
\text { (thousands) }\end{array}$ & communes & people \\
\hline 1 & high EL/high ED & 230 & $2,328.5$ & 10.6 & 15.4 \\
\hline 2 & average EL/average ED & 663 & $4,403.2$ & 30.5 & 29.1 \\
\hline 3 & low EL/low ED & 316 & $1,802.0$ & 14.5 & 11.9 \\
\hline 4 & low EL/high ED & 23 & 129.0 & 1.1 & 0.9 \\
\hline 5 & high EL/low ED & 42 & 350.8 & 1.9 & 2.3 \\
\hline 6 & average EL/high ED & 140 & $1,085.5$ & 6.4 & 7.2 \\
\hline 7 & low EL/average ED & 331 & $1,759.0$ & 15.2 & 11.6 \\
\hline 8 & high EL/ average ED & 166 & $1,440.3$ & 7.6 & 9.5 \\
\hline 9 & average EL/ low ED & 262 & $1,854.3$ & 12.1 & 12.2 \\
\hline & Total & 2173 & $151,526.0$ & 100.0 & 100.0 \\
\hline
\end{tabular}

Source: own elaboration. EL - education level, ED - economic development level. 
type four where, despite a low education level, the level of economic development is extraordinary. There are 23 such communes, located in West Pomerania (7), Małopolska (3), Lower Silesia (3), Pomerania, Warmia-Mazuria, Wielkopolska (two in each) as well as in Silesia and Lubuska Land (one in each). Those are areas of high location rent resulting from their location on the western border of Poland or in areas attractive for tourists (e.g. Mikołajki and Orzysz in Warmia-Mazuria).

In turn, the fifth type includes areas where high educational attainment goes with a low level of economic development. There are 42 such communes (almost $2 \%$ of the total number), inhabited by $2.3 \%$ of the Polish rural population. Almost all of them are located in south-eastern Poland: Subcarpathia (14), Świętokrzyska Land (9), Lublin (8), and Małopolska (5). Five communes are located in Mazovia, but all of them (with no exception) on the border with Świętokrzyska Land. In the spatial layout, those are primarily areas located peripherally in the voivodeships, which may prove that even a high education level of the inhabitants along with an unfavourable location

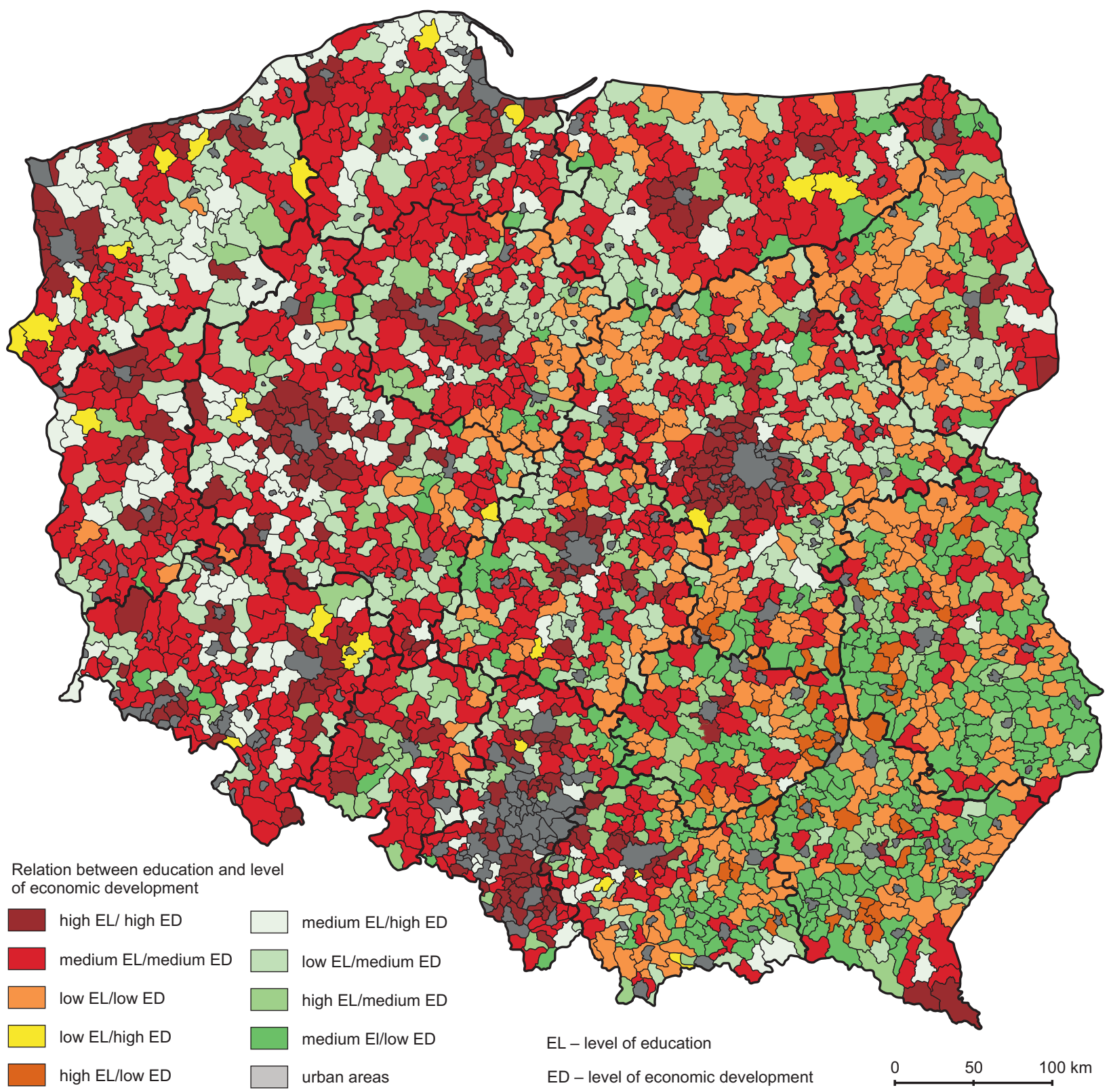

Fig. 4. Typology of communes by the relation between education and the level of economic development. 
does not translate into a proportional level of economic development.

Types six to eight include communes where differences between the analysed features do not exceed one level (high - average, average - low). Altogether there are 899 units (41.3\%) of this type, inhabited by $40.5 \%$ of rural inhabitants. Of course, the situation is more favourable in types six and eight than in types seven and nine. In areas where an average level of education goes with a high level of economic development (type 6), one can assume that the material factors of development are strong enough to create extraordinary economic growth. Usually such areas are characterised by a well developed non-agricultural labour market and a net in-migration. The following communes may serve as an example: Solina in Subcarpathia - an area with well developed tourist functions, Połaniec in Świętokrzyska Land, Puchaczów in Lublin, Bogatynia in Lower Silesia with industrial functions, and Tuszyn in Łódź, where a trade function has developed. Thus, one can expect that progress in the education of the local society and the analysed features may affect each other synergically in the future. The communes representing type six are located mostly in the western part of Poland: Wielkopolska (31), Lower Silesia (22) and West Pomerania (21).

Type eight includes communes where high education goes with an average level of economic development. Those units are concentrated in south-eastern voivodeships: Lublin (21), Mazovia (21 - the eastern and southern parts), Subcarpathia (19), Małopolska (15), and Opole (13). The favourable structure of the population's education results from its access to higher education (location in the vicinity of big university centres). Factors that impede an adequate level of economic development here are external and internal labour-related migrations (Heffner, Rauziński 2013), lack of local leaders as well as passivity of some of the best educated people. Moreover, fragmented agriculture dominates in these areas, where young people escape unemployment by extending the period of education. Unfortunate$\mathrm{ly}$, despite acquiring at least secondary education, they enlarge so-called disguised unemployment. In my view, a good structure of education may stimulate the economic development of these areas in the future.
Type seven includes areas where a low level of education and an average level of economic development were observed. These communes are concentrated mostly in central Poland (Mazovia - 64, Wielkopolska - 38, Kujavia-Pomerania - 30, Łódź - 35) and western Poland (West Pomerania - 26, Lower Silesia - 21). The situation of agriculture is good there. One should also note that even a good situation of agriculture translates at most into an average level of socio-economic development.

Units characterised by an average level of education and a low level of economic development were classified into type nine. There are 262 communes $(21.1 \%$ of their total number) of this type, located mostly in four voivodeships: Lublin (80), Subcarpathia (56), Małopolska (37) and Świętokrzyska Land (26). The units concentrated in those four voivodeships accounted for threefourths of communes representing type nine. The population that dominates in these areas is rural and agricultural, usually characterised by a lower level of educational attainment than the inhabitants of cities (Frenkel 2012). However, in the case of fragmented and semi-subsistence agriculture, even the secondary level of education does not translate into a favourable (at least average) level of economic development.

\section{Summing up}

The above analysis allows one to state that there are vast regional disproportions, both in the educational attainment of the population and the level of economic development in the Polish rural areas.

The spatial diversification of the level of education can be analysed in terms of the core-periphery theory. The best educated citizens live in areas located in the influence zones of the biggest urban centres. The size of this zone depends on the size of a city and may include communes located in the first and second ring, but the influence of the city is not equal in all directions. For example, in the case of Warsaw, the communes neighbouring on the capital from the west are characterised by a higher level of education than the inhabitants of units stretching to the east of the capital. With the growing distance from the national urban centres, the level of education of 
the rural population decreases. The most unfavourable structure of the population's education occurs in areas located peripherally in the voivodeships.

Clearly visible is the division of Poland, in terms of the level of economic development, into the western part characterised by superior values of the synthetic measure of development and the eastern part in a definitely worse economic condition, which results from historical factors (the partition of Poland). At the same time, the influence of urban centres on the development of areas included in their zone of influence becomes uncontested, which results in the division of the urban areas into integrated rural areas (located in the suburban zones of large cities) as well as indirect and peripheral rural areas (Wilkin 2007). Rosner and Stanny (2007) achieved similar results during a research on differences in the socio-economic development of rural areas, and so did Bański (2008) while identifying fields of economic success.

The research has shown a significant linear relation between the educational attainment of the population and the level of economic development of rural areas. The correlation coefficient amounts to 0.565 , and the coefficient of determination $\mathrm{r}^{2}=0.319$. However, it is hard to state unequivocally whether it is the level of education that stimulates economic growth or vice versa. I think that, so far, the rural population's qualifications are a secondary factor in the Polish circumstances. It results from the finding (Bański 2008, Kamińska 2010) that the primary factors of economic development are historical determinants (being part of the given partition), natural determinants (raw-material resources, conditions for the development of agriculture), location rent (a favourable location with respect to cities, areas attractive for tourists) as well as the presence of an economic entity (an industrial works, service providers) of at least regional significance (e.g. a voivodeship hospital in Morawica commune or a power plant in Połaniec commune - both examples from Świętokrzyska Land). The development of non-agricultural functions has caused an influx of highly qualified staff and the necessity to improve the education of the local society.

Suburban areas are especially privileged, with their high level of education going with a superi- or level of economic development. Thanks to the synergic effect of both features, those are the areas of economic success with good prospects for the future.

In the case of a peripheral location, even a superior level of education is not a factor leading to economic development even at an average level.

Communes may reach a high level of economic development in some specific cases even with an unfavourable education structure. This is possible only if an economic entity of supra-regional importance operates in the given area. It diversifies the economic structure of the commune, creates non-agricultural workplaces, and results in an increase in local government's own revenues.

The economic situation is unsatisfactory in areas where the agricultural function dominates. It concerns both, communes with intensive, large-area farming, as well as those with the family-operated type - neither intensive, nor commodity-oriented. The difference between these communes is such that in the first case the level of economic development is average (in relation to Poland) and farming enables adequate living conditions for a farmer and his family, whereas in the second case, the level of economic development is lower than the average and farmers are forced to look for additional sources of income (often unearned sources: pensions, other social benefits). This is because agriculture does not create additional workplaces and does not increase the communes' revenues. It would be worthwhile to discuss a reform of the farmers' social security system (KRUS).

Spatial regularities were determined in the location of communes of various types:

1. communes with a high level of both analysed features are located around the biggest agglomerations,

2. communes included in types eight and nine are located mostly in south-eastern Poland, with the predominance of units performing agricultural and mixed functions characterised by fragmented family farming,

3. most units of type six are in north-western Poland, which is characterised by a significant share of non-agricultural functions, where communes with mixed and forest functions dominate,

4. units of type three are located mostly in north-eastern Poland where a whole range of 
functions dominate in each commune and all the functions occur,

5. communes included in type two are located mostly in south-western Poland characterised by well developed non-agricultural functions,

6 . in central Poland where functional diversification is observed, the type of commune depends on its location with respect to a city. Communes of types one and two concentrate in the vicinity of urban centres. Communes of type two (in the case of a significant share of non-agricultural functions) or types six and seven (in the case of dominating agricultural functions) dominate farther from cities.

\section{References}

Acemoglu D., 1996. Microfoundation for social increasing returns in human capital accumulation. Quarterly Journal of Economics 111 (3): 779-804.

Acemoglu D., Autor D., 2012. What does human capital do? A review of Golding and Katz's The Race between Education and Technology. Journal of Economic Literature 50(2): 426-63.

Adebiyi M.A., Oladele O., 2005. Public education expenditure and defense spending in Nigeria: An empirical investigation. http//www.saga.cornell.educ /saga/ educconf/ adebiyi.pdf (accessed 12 December 2012).

Arrow K., 1962. The economic implications of learning by doing. Review of Economic School Studies 29: 155-173.

Bacon F., 1620 (Polish edition 1995). Novum Organum. PWN, Warszawa.

Baldacci E., Clements B., Gupta S., Cui Q., 2008. Social spending, human capital, and growth in developing countries. World Development 36: 1317-1341.

Bański J., 2003. Pozarolniczy rozwój gospodarczy na obszarach wiejskich w Polsce (Non-agricultural economic development in the rural areas of Poland). Przeglad Geograficzny 75(3): 385-401.

Bański J., 2008. Wiejskie obszary sukcesu gospodarczego (Economically successful rural areas). Studia Obszarów Wiejskich, vol. 14, IGiPZ PAN, PTG, Warszawa.

Bański J., Stola W., 2002. Przemiany struktury przestrzennej $i$ funkcjonalnej obszarów wiejskich (Transformation of the spatial and functional structure of rural areas in Poland). Studia Obszarów Wiejskich, vol. 3, PTG, IGiPZ PAN, Warszawa.

Barrett A., 2001. Economic performance of education and training: Costs and benefits. In: Descy P., Tessaring M. (eds), Training in Europe. Second report on vocational training research in Europe. Luxembourg, Office for Official Publications of the European Communities. Vol. II, Part 4: 383-404.

Barro R.J., 1998. Human capital and growth in cross-country regressions. Working paper, Harvard University.

Barro R.J., Lee J.W., 1996. International measures of schooling years and schooling quality. American Economic Review Papers and Proceedings 86: 218-223.
Barro R.J., Lee J.W., 2000. International data on educational attainment: Updates and implications. CID working paper 42, www.cidwp/042.htm (accessed 15 December 2011).

Barro R.J., Lee J.W., 2010. A new data set of educational attainment in the world, 1950-2010. NBER working paper 15902, National Bureau of Economic Research (April), Cambridge, MA.

Becker G.S., 1964. Human capital: A theoretical and empirical analysis with special reference to education. University of Chicago Press, Chicago.

Bils M., Klenow P., 2000. Does schooling cause growth? American Economic Review 90: 1160-1183.

Blundell R., Dearden L., Sianesi B., 2001. Estimating the returns to education: Models, methods and results. CEE - Centre for the Economics of Education (LSE), Discussion paper 16, London.

Buchinsky M., 1994. Changes in the US wage structure 19631987: An application of quantile regression. Econometrica 62(2): 405-458.

Caselli F., Esquivel G., Lefort F., 1996, Reopening the convergence debate: A new look at cross-country growth empirics. Journal of Economic Growth 1(3): 363-389.

Cooray A.V., 2009. The role of education in economic growth. Proceedings of the 2009 Australian Conference of Economists. South Australian Branch of the Economic Society of Australia, Adelaide, Australia: 1-27.

de Barros R.P., Henriques R., Mendonça R., 2000. Education and equitable economic development. Economia 1(1): 111-144.

de la Fuente A., Ciccone A., 2003. Human capital in a global and knowledge-based economy. Working papers 562.03, Unitat de Fonaments de l'Anàlisi Econòmica (UAB) and Institut d'Anàlisi Econòmica (CSIC).

Denison E.F., 1971. Education, economic growth, and gaps in information. In: Wykstra R.A. (ed.), Education and the economics of human capital. Collier-Macmillan, London.

Denny K., O'Sullivan V., 2007. Can education compensate for low ability? Evidence from British data. Applied Economics Letters 14(19): 657-670.

Descy P., Tessaring M., (eds), 2001. Training in Europe. Second report on vocational training research in Europe: Background report. Office for Official Publications of the European Communities, Luxembourg.

Eberhardt P., 1989. Regiony wyludniajace się w Polsce (Depopulating regions in Poland). Prace Geograficzne 148 , IGiPZ PAN, Warszawa.

Flabbi L., Paternostro S., Tiogson E.R., 2007. Returns to education in the economic transition: A systematic assessment using comparable data. Policy Research working paper 4225, World Bank, Washington DC.

Fleisher, B., Wang X., 2004. Skill differentials, return to schooling, and market segmentation in a transition economy: The case of mainland China. Journal of Development Economics 73: 715-728.

Fleischer B.M., Li H., Zhao M.Q., 2008. Human capital, economic growth, and regional inequality in China. Working paper 3576, Institute for the Study of Labor (IZA).

Frenkel I., 2012. Ludność wiejska (Rural population). In: Frenkel I., Nurzyńska I. (eds), Polska wieś 2012. Raport o stanie wsi. Fundacja na rzecz Rozwoju Polskiego Rolnictwa. Wyd. Scholar, Warszawa.

Grodzicki J., 2003. Rola kapitału ludzkiego w rozwoju gospodarki globalnej (Role of human capital in development of the global economy). Wyd. Uniwer. Gdańskiego, Gdańsk. 
Grootaert Ch., van Bastelaer T., 2002. Understanding and measuring social capital. A synthesis of findings and recommendation from the social capital initiative. Forum Series on the Role of Institutions and Promoting Economic Growth, Washington.

Hanushek, E.A., Woessmann L., 2008. The role of cognitive skills in economic development. Journal of Economic Literature 46(3): 607-668.

Hanushek E.A., Woessmann L., 2012. Schooling, educational achievement, and the Latin American growth puzzle. Journal of Development Economics 99(2): 497-512.

Harbison F., Meyers Ch., 1964. Education, manpower and economic growth. McGraw-Hill, New York.

Harmon C., Oosterbeek H., Walker I., 2003. The returns to education: A review of evidence, issues and deficiencies in the literature. Journal of Economic Surveys 17(2): 115-116.

Harmon C., Walker I. , 2001. The returns to education: A review of the evidence, issues, and deficiencies in the literature. Sheffield: Department for Education and Skills. (Research report).

Heffner K., Rauziński R., 2013. Predominantly rural region as migration region, its evolution in Poland. The case study of Opole Silesia. In: Kamińska W., Heffner K., (eds), Processes of Transformation of Rural Areas. Studia Regionalia KPZK PAN. Warszawa (in press).

Heffner K., Rosner A., 2005. Czynniki rozwoju obszarów wiejskich - rola małych miast (Factors of rural development - the role of small towns) In: Rosner A. (ed.), Uwarunkowania i kierunki przemian społeczno-gospodarczych na obszarach wiejskich. IRWiR PAN, Warszawa: 229-330.

Hellwig Z., 1968. Zastosowanie metody taksonomicznej do typologicznego podziału krajów ze względu na poziom ich rozwoju oraz zasoby i strukturę wykwalifikowanych kadr (Taxonomic method application for a typological division of states by their level of development as well as resources and structure of qualified workforce). Przeglad Statystyczny 4 .

Heston A., Summers R., Aten B., 2002. Penn World, Table Version 6.1. Center for International Comparisons at the University of Pennsylvania (CICUP).

Hryniewicz J.T., 2000. Endo- i egzogenne czynniki rozwoju gospodarczego gmin i regionów (Endogenic and exogenic factors of economic development of communes and regions). Studia Regionalne i Lokalne 2(2): 53-77.

Janc K., Czapiewski K.Ł., 2005. Wykształcenie czynnikiem wspierającym rozwój gospodarczy obszarów wiejskich (Education as a factor facilitating economic development of rural areas). In: Głębocki B., Kaczmarek U., (eds), Obszary sukcesu na polskiej wsi. Studia Obszarów Wiejskich 8, IGiPZ PAN, PTG, Warszawa: 69-84.

Jimenez E., Nguyen V., Patrinos H.A., 2012. Stuck in the middle? Human capital development and economic growth in $\mathrm{Ma}$ laysia and Thailand. Policy Research working paper 6283, World Bank, Washington DC.

Judson R., 1998. Economic growth and investment in education. How allocation matters? Journal of Economic Growth 3: 337-359

Kamińska W., 2005. Aktywność gospodarcza osób fizycznych na obszarach wiejskich Polski południowej (Economic activity of individuals in the rural areas of south Poland). Wiadomości Statystyczne 7: 49-59.

Kamińska W., 2010. Urbanizacja obszarów wiejskich województwa świętokrzyskiego (Urbanisation of the rural areas of Świętokrzyska Land). IG UJK, Kielce.
Kamińska W., 2011a. Aktywność gospodarcza osób fizycznych na obszarach wiejskich w Polsce (Economic activity of natural persons in rural areas in Poland). In: Kamińska W., Heffner K. (eds), Obszary wiejskie: wielofunkcyjność, migracje, nowe wizje rozwoju. Studia KPZK PAN, vol. CXXXIII, Warszawa: 103-127.

Kamińska W., 2011b. Kapitał ludzki i społeczny na obszarach wiejskich w Polsce. Przykład województwa świętokrzyskiego (Human and social capital in rural areas of Poland. The case of Świętokrzyska Land). IG UJK, Kielce.

Kamińska W., 2012. Kapitał ludzki jako czynnik stymulujący rozwój gospodarczy obszarów wiejskich? Przykład województwa świętokrzyskiego (Human capital as a factor stimulating economic growth of rural areas? Swiętokrzyska Land Case). Acta Scientiarum Polonorum. Administratio Locorum 11(3): 109-125.

Kamińska W., Heffner K. (eds), 2010. Kapitał ludzki i społeczny w procesie rozwoju obszarów wiejskich (Human and social capital in the process of rural development). Studia KPZK PAN, vol. CXXVI, Warszawa.

Kamińska W., Heffner K. (eds), 2011. Obszary wiejskie: wielofunkcyjność, migracje, nowe wizje rozwoju (Rural areas: multi-functionality, migration, new visions of development). Studia KPZK PAN, vol. CXXXIII, Warszawa.

Kharas H., Kohli H., 2011. What is the middle income trap, why do countries fall into it, and how can it be avoided? Global Journal of Emerging Market Economies 3(3): 281-289.

Kendrick J.W., 1961. Productivity trends in the United States. A study by the National Bureau of Economic Research. Princeton University Press, New York.

Kirchhoff, B., Newbert, S., Hasan, I., Armington C., 2007. The influence of university R\&D expenditures on new business formations and employment growth. Entrepreneurship Theory and Practice 31: 543-559.

Kłodziński M., 2006. Aktywizacja społeczno-gospodarcza gmin wiejskich $i$ matych miast (The socio-economic activation of rural areas and small towns). IRWiR, Warszawa.

Kulikowski R., 2001. Problemy społeczne wsi i rolnictwa w Polsce (Social issues of the countryside and agriculture in Poland). In: Bański J., Rydz E. (eds), Społeczne problemy wsi. Studia Obszarów Wiejskich 2, IGiPZ PAN, PTG, Warszawa: 9-17.

Lucas R., 1988. On the mechanics of economics development. Journal of Monetary Economics 22: 3-42.

Mankiw N.G., Romer D., Weil D.N., 1992. A contribution to the empirics of economic growth. Quarterly Journal of Economics 107: 407-437.

McMahon, W.W., 2001. The impact of human capital on non-market outcomes and feedbacks on economic development. In: Helliwell J.F. (ed.), The contribution of human and social capital to sustained economic growth and well being. Government of Canada, Hull, Quebec.

Marx K., 1867 (first published), 1890. Das Kapital. Kritik der politischen Ökonomie (Capital: Critique of political economy). Verlag von Otto Meissner, Hamburg.

Mill J.S., 1848 (first published), 1909. The principles of political economy: With some of their applications to social philosophy. Longmans Green \& Co., London.

Miller H.P., 1960. Annual and lifetime income in relation to education. American Economic Review 50: 962-986.

Munich D., Svejnar J., Terrell K., 2004. Do markets favor women's human capital more than planners? IZA discussion paper 1393, Bonn.

Mwabu G., Schultz T., 1996. Education returns across quantiles of the wage functions: Alternative explanations for 
returns to education by race in South Africa. American Economic Review 86(2): 335-339.

Nelson R., Phelps E., 1966. Investment in humans, technological diffusion, and economic growth. American Economic Review 56: 69-75.

Newell A., Socha M.W., 2005. The distribution of wages in Poland, 1992-2002. IZA discussion paper no. 1485, Bonn.

Petty W., 1676 (first published), 1899. Political arithmetic. In: Hull Ch.H. (ed.), The Economic Writings of Sir William Petty. Cambridge University Press, Cambridge, UK: 233313.

Pritchett L.,1999a. Where has all the education gone? Policy Research working paper, World Bank, Washington DC.

Pritchett L., 1999b. Has education had a growth payoff in the Mena region? Discussion paper, World Bank, Washington DC.

Pritchett L., 2001. Where has all the education gone? World Bank Economic Review 15(3): 367-391.

Przybyszewski R., 2007. Kapitał ludzki w procesie kształtowania gospodarki opartej na wiedzy (Human capital in the process of developing a knowledge-based economy). Wyd. Diffin, Warszawa.

Psacharopoulos G., Patrinos H.A., 2004. Returns to investment in education: A further update. Education Economics 12: 111-134.

Romer P.M., 1990. Endogenous technological change. Quarterly Journal of Economics 98: 71-102.

Rosner A., (ed.), 2007. Zróżnicowanie rozwoju społeczno-gospodarczego obszarów wiejskich a zróżnicowanie dynamiki przemian (Diversification of socio-economic development of rural areas vs. diversification of transformation dynamics). IRWiR PAN, Warszawa.

Rosner A., 2011. Zróżnicowanie zaludnienia obszarów wiejskich w Polsce. Obszary zmniejszające zaludnienie i koncentrujące ludność (Diversification of population in rural areas of Poland. Areas of population growth and decline). In: Kamińska W., Heffner K. (eds), Dychotomiczny rozwój obszarów wiejskich? Czynniki progresji, czynniki peryferyzacji. Studia KPZK PAN, CXXVI: 125-139.

Rosner A., Stanny M., 2007. Zróżnicowanie przestrzenne aktywności władz lokalnych w korzystaniu z instrumentów polityki rozwoju gminy (Spatial diversification of local governments' activity in utilisation of instruments of a commune's development policy). In: Rosner A. (ed.),
Zróżnicowanie rozwoju społeczno-gospodarczego obszarów wiejskich a zróżnicowanie dynamiki przemian. IRWiR PAN, Warszawa.

Schlump Ch., Brenner T., 2010. University education, public research and employment growth in regions - an empirical study of Germany. Philipps-Universität Marburg.

Sianesi B., van Reenen J., 2000. The returns to education: A review of the macro-economic literature. London: CEE - Centre for the Economics of Education (LSE), Discussion paper 6.

Smith A., 1776 (first published),1904. The wealth of nations. Methuen and Co., London (fifth edition).

Stanny M., Czarnecki A., 2011. Zrównoważony rozwój obszarów wiejskich Zielonych Płuc Polski. Próba analizy empirycznej (Sustainable development of areas of Rural Green Lungs of Poland. Attempt at an empirical analysis). IRWiR PAN, Warszawa.

Stasiak A. (ed.), 2000. Możliwości wielofunkcyjnego rozwoju wsi polskiej w kontekście integracji z Unia Europejska (Opportunities for multifunctional rural development in Poland in the context of European Union integration). Studia KPZK PAN, CX, Warszawa.

Thurow L.C., 1999. The future of capitalism. How do contemporary economic forces form the world of tomorrow. Wydawnictwo Dolnośląskie, Wrocław.

Wilkin J., 2007. Obszary wiejskie w warunkach dynamizacji zmian strukturalnych. Ekspertyza do Strategii Rozwoju SpołecznoGospodarczego Polski Wschodniej do 2020 r. (Rural areas in the circumstances of dynamisation of structural changes. Expert's report for the Strategy of Socio-Economic Development of Eastern Poland till 2020). MRR, Warszawa.

Wilson R.A., Briscoe G., 2004. The impact of the human capital on economic growth: A review. In: Descy P., Tessaring M. (eds), Impact of education and training. Third Report on Vocational Training Research in Europe: Background Report 54. Office for Official Publications of the European Communities, Luxembourg: 9-70.

Zegar J., 2000, Kierunki rozwoju rolnictwa obszarów wiejskich - uwarunkowania regionalne (Directions of agricultural and rural development - regional conditions). In: Stasiak A. (ed.), Możliwości wielofunkcyjnego rozwoju wsi polskiej w kontekście integracji z Unią Europejską. Studia KPZK PAN CX, Warszawa: 23-36. 